e-ISSN : 2621-4105

\title{
FAKTOR PENYEBAB TERJADINYA TINDAK PIDANA KEJAHATAN NARKOTIKA
}

\author{
Fuad Alghi Fari, Susi Fitria Dewi \\ Universitas Negeri Padang, Indonesia \\ fuadalghifari20.faf@gmail.com
}

\begin{abstract}
Abstrak
Artikel ini bertujuan untuk menggambarkan bagaimana faktor-faktor penyebab terjadinya tindak kejahatan Narkoba di Bukittinggi (studi kasus narapida di Lembaga Pemasyarakatan kelas IIA Bukittinggi). Penelitian ini dilakukan di lembaga pemasyarakatan kelas IIA Bukittinggi. Pendekatan dalam penelitian ini adalah pendekatan kualitatif. Hasil penelitian menunjukan bahwa faktor penyebab terjadinya tindak kejahatan Narkoba di kota Bukittinggi disebabkan oleh faktor rendahnya pemahaman agama, faktor rendahnya pendidikan, faktor lingkungan dan faktor keluarga.
\end{abstract}

\section{Kata Kunci: Faktor; Kejahatan; Narkoba.}




\title{
FACTORS THAT CAUSE THE OCCURRENCE OF DRUG CRIME
}

\begin{abstract}
This article aims to describe the factors that cause the occurrence of drug crimes in Bukittinggi (a case study of prisoners in the Bukittinggi class IIA Penitentiary). This research was conducted in a class IIA Bukittinggi penitentiary. The approach in this research is a qualitative approach. Data obtained through observational interviews, documentation studies, and FGD (focus group discussion). Data analysis using data analysis techniques Miles and Huberman which consists of data reduction, data presentation and decision making. The validity of the data was tested by source triangulation. The results showed that the factors causing the occurrence of drug crime in the city of Bukittinggi were caused by low religious understanding, low education, environmental factors and family factors.
\end{abstract}

\section{Keywords: Factor; Crime; Drugs.}




\section{A. PENDAHULUAN}

Narkoba adalah singkatan dari Narkotika Psikotropika dan obat berbahaya lainnya. Istilah lain yang diperkenalkan khususnya oleh Kementrian Kesehatan Republik Indonesia adalah Napza yang merupakan singkatan dari Narkotika, Psikotropika dan zat adiktif. Semua istilah ini, baik Narkoba dan Napza, mengacu pada sekelompok zat pada umumnya mempunyai resiko kecanduan bagi penggunanya. ${ }^{1}$

Narkotika disatu sisi merupakan obat atau bahan yang bermanfaat dibidang pengobatan atau pelayanan kesehatan, pengembangan ilmu pengetahuan, dan disisi lain dapat pula menimbulkan ketergantungan yang sangat merugikan karena dipergunakan tanpa pengendalian dan pengawasan yang ketat dan seksama. Menurut pakar kesehatan, narkoba sebenarnya adalah psikotropika yang biasa dipakai untuk membius pasien saat hendak dioperasi atau obat-obatan untuk penyakit tertentu. Namun kini pemanfaatannya disalah gunakan diantaranya dengan pemakaian yang telah diluar batas dosis/overdosis. ${ }^{2}$

Pemerintah akhir-akhir ini terus mendorong masyarakat melalui berbagaikesempatan untuk lebih peduli terhadap ancaman bahaya nasional yang harusditanggulangi secara tuntas dan konsepsional. ${ }^{3}$ Sesuai dengan UU RI Nomor 35 Tahun 2009 Tentang Narkotika pada Bab I Pasal I, Narkotika adalah zat atau obat yang berasal dari tanaman atau bukan tanaman, baik sintetis maupun semisintetis, yang dapat menyebabkan penurunan atau perubahan kesadaran, hilangnya rasa nyeri dan dapat menimbulkan ketergantungan.

Permasalahan Narkoba di Indonesia masih merupakan sesuatu yang bersifat urgent dan kompleks, dalam kurun waktu satu dekade terakhir permasalahan ini menjadi marak. Terbukti dengan bertambahnya jumlah penyalahguna atau pecandu narkoba secara signifikan, seiring meningkatnya pengungkapan kasus tindak kejahatan narkoba yang semakin beragam polanya dan semakin masif pula jaringan sindikatnya. ${ }^{4}$

\footnotetext{
${ }^{1}$ Gunawan Gunawan "Peran Masyarkat Dalam Pencegahan Dan Penanggulangan Terhadap Penyalahgunaan Dan Peredaran Gelap Narkotika", Jurnal Sociae Polites 15 (2), 2014, hal 46-62.

2 Iredo, (2016). "Peran Orang Tua Dalam Penanggulangan Penyalahgunaan Narkoba Pada Generasi Muda”, Jurnal Psikologi Islami 2 (1), 2016, hal 40-49.

${ }^{3}$ Hafrida Hafrida, "Kebijakan Hukum Pidana Terhadap Penggunaan Narkotika Sebagai Korban Bukan Pelaku Tindak Pidana: Studi Lapangan Daerah Jambi”, Jurnal Padjajaran Jurnal Ilmu Hukum 3 (1), 2016, hal 13-25.

4 Maudy Pritha Amanda dkk, "Penyalahgunaan Narkoba Di Kalangan Remaja". Jurnal Penelitian dan PPM 4 (2), 2017, hal 129-389. DOI: https://doi.org/10.24198/jppm.v4i2.14392
} 
Dari data-data dan hasil penelitian Badan Narkotika Nasional (BNN), bahwa penyalahgunaan dan peredaran gelap narkotika terbukti merasuk kesemua pelosok kota dan desa serta kesetiap lapisan masyarkat. Data BNN menunjukkan kasus-kasus tindak pidana Narkotika dari tahun ketahun selalu meningkat, pada tahun 2014 tercatat 22.750 kasus, beberapa tahun berikutnya angka itu tidak mengalami penurunan, terlihat pada tahun 2015 data sudah melonjak lebih dari delapan kali lipat menjadi 27.950 kasus. Dan pada tahun 2016 tercatat pengguna narkotika berjumlah 35.401 (BNN, 2017). ${ }^{5}$

Tentu saja hal ini membuat para orang tua, masyarakat dan pemerintah, pemimpin sekolah maupun perguruan tinggi khawatir akan penyebaran narkotika yang begitu meraja rela. Peredaran narkoba semakin marak terjadi bahkan pasar yang ada dirasakan meluas di berbagai daerah, seperti di daerah Sumatera Barat tepatnya di kota Bukittinggi adalah salah satu pasar narkoba.

Bukittinggi merupakan pasar ke dua terbesar di Provinsi Sumatera Barat. ${ }^{6}$ Telah banyaknya penangkapan dan penggrebekan yang dilakukan oleh jajaran unit narkoba Polres Bukittinggi tidak menyurutkan pelaku, baik produsen maupun pengedar ataupun pengguna untuk berhenti berurusan dengan narkoba. Upaya yang dilakukan oleh satuan narkoba Polres Bukittinggi sudah banyak seperti penyuluhan tentang bahaya narkoba bagi kesehatan dan apa bahaya dari pemakaian narkoba, ini sudah diberikan penyuluhan terhadap masyarakat, dan sekolah oleh satuan unit narkoba Polres Bukittinggi dan BNN.

Penelitian tentang faktor penyebab tindak pidana narkotika pernah diteliti sebelumnya oleh Siregar (2019) yang berjudul "Analisis Faktor-Faktor Penyebab Anak Melakukan Tindak Pidana Narkotika”. Penelitian tersebut mengkaji faktor faktor apa yang menyebabkan anak-anak menjadi korban dari tindak pidana narkotika. Penelitian ini secara khusus hanya meneliti tentang faktor penyebab anak-anak dalam tindak pidana narkotika. Faktor penyebab anak-anak terjerumus penyalahgunaan narkotika adalah kurangnya perhatian dari prang tua, adanya broken home, perubahan status sosial dan gaya hidup, adanya permasalahan dalam pelajaran, meluasnya pergaulan dan mendapatkan informasi yang salah terkait dengan narkotika. ${ }^{7}$

\footnotetext{
${ }^{5}$ Badan Narkotika Nasional, "Hasil Survei Penyalahgunaan Dan Peredaran Gelap Narkoba Pada Kelompok Pelajar Dan Mahasiswa Di 18 Provinsi Tahun 2016”, Jurnal Data Puslitdatin BNN 10 (2), 2016, hal 1-12

${ }^{6}$ Ibid. Pasal 1 Angka 5 Undang-undang Nomor 48 Tahun 2009 tentang Kekuasaan Kehakiman.

${ }^{7}$ Gomgom T.P. Siregar dkk (2019), “Analisis Faktor-Faktor Penyebab Anak Melakukan Tindak Pidana Narkotika”. Jurnal Penelitian Pendidikan Sosial Humaniora 4 (2) hal 580-590.
} 
Sedangkan penelitian oleh Novitasari (2021) yang berjudul "Proses Penegakan Hukum Terhadap Tindak Pidana Penyalahgunaan Narkotika Yang Dilakukan Oleh Anak" lebih banyak mengkaji faktor-faktor apakah yang berpengaruh terhadap anak yang terlibat dalam penyalahguna narkotika dan bagaimana proses penegakan hukum penyalahguna narkotika yang dilakukan oleh anak-anak. Rasa penasaran dan ingin memperoleh pengalaman baru menjadi salah satu faktor anak-anak terjerumus dalam penggunaan narkotika. Sedanagkan penegakan hokum bagi anak pelaku tindak pidana narkotika di Indonesia telah diatur dalam Undang-Undang Nomor 17 Tahun 2016 tentang Perubahan Kedua Atas Undang-Undang Nomor 23 Tahun 2002 tentang Perlindungan Anak dan Undang-Undang Nomor 11Tahun 2012 tentang Sistem Peradilan Pidana Anak. ${ }^{8}$

Penelitian oleh Pangaribuan (2020) yang berjudul "Efektifitas Pemidanaan Terhadap Pelaku Tindak Pidana Narkotika: Studi Pengadilan Negeri Pasangkayu" lebih banyak mengkaji tentang seberapa jauh efektifnya pemidanaan kepada pelaku tindak pidana narkotika dan faktor- faktor apa yang berpengaruh dalam memberikan efek jera dalam terhadap pelaku tindak pidana narkotika. Penelittia ini dilakanakan di Pengadilan Negeri Pasangkayu. Hasil dari penelitian tersebut yaitu adanya efek jera dalam proses pemidanaan terhadap kasus tindak pidana narkotika, hal ini terbukti dari semakin menurunnya kasus tindak pidana narkotika di Pengadilan Negeri Pasangkayu. Faktor substansi hokum merupakan fakltor yang dominan berpengaruh dalam menurunnya angka tindak pidana narkotika. ${ }^{9}$

Penelitian tentang faktor penyebab tindak pidana narkotika yang diteliti oleh Gomgom T.P. Siregar Perlindungan dan Novi Novitasari secara khusu hanya meneliti tentang tidak pidana narkotika yang dilakukan oleh anak-anak. Penelitian oleh Dian Arthauly Pangaribuan lebih banyak membahas tentang efektifnya pemidanaan terhadap pelaku tindak pidana narkotikan dan faktor- yang dapat memberikan efek jera kepada pelaku tindak pidanan narkotika. Sedangkan penelitian ini lebih melengkapi penelitian

8 Novi Novitasari dkk (2021),"Proses Penegakan Hukum Terhadap Tindak Pidana Penyalahgunaan Narkotika Yang Dilakukan Oleh Anak”. Jurnal Pembangunan Hukum Indonesia 2 (1) hal 96-108.

DOI: https://doi.org/10.14710/jphi.v3i1.96-108

${ }^{9}$ Dian Arthauly Pangaribuan dkk (2020), "Efektifitas Pemidanaan Terhadap Pelaku Tindak Pidana Narkotika: Studi Pengadilan Negeri Pasangkayu", Journal of Lex Generalis 1 (4) hal 542-554. DOI: https://doi.org/10.52103/jlg.v1i4.181 
e-ISSN : 2621-4105

sebelumnya dengan fokus kajian tentang faktor-faktor penyebab terjadinya tindak kejahatan narkotika dengan lokasi penelitian di Kota Bukittinggi. Tujuan dari penelitian ini bagaimana faktor-faktor penyebab terjadinya tindak kejahatan narkotika di Kota Bukittinggi.

\section{B. PERMASALAHAN}

Dari uraian di pendahuluan tadi telah digambarkan tentang tingginya tindak pidana narkotika di Kota Bukitinggi, permasalahan yang diangkat di penelitian ini adalah bagaimana faktor-faktor penyebab terjadinya tindak kejahatan narkotika di kota Bukittinggi ?

\section{METODE PENELITIAN}

Penelitian ini menggunakan pendekatan kualitatif. Penelitian kualitatif merupakan "penelitian yang mendeskripsikan suatu fenomena dengan kata-kata menggunkana metode-metode ilmiah". ${ }^{10}$ Penelitian ini menggunakan teknik observasi, wawancara, FGD (focus group discussion) dan studi dokumentasi untuk mendapatkan data terkait faktor penyebab terjadinya tindak pidana kejahatan Narkoba di Bukittinggi. Observasi dilakukan dengan cara mengamati secara langsung lembaga pemasyarakatan kelas II A Bukittinggi. Wawancara dilakukan untuk mengetahui faktor-faktor penyebab terjadinya tindak pidana kejahatan Narkoba. Informan terdiri dari naripida lembaga pemasyarakatan kelas II A Bukittinggi, Kepala lembaga pemasyarakatan kelas II A Bukittinggi, Badan Narkotika Nasioanal (BNN) Bukittinggi, Polisi Resor (POLRES) Bukittinggi. FGD dilakukan untuk mendengarkan keterangan, pendapat, dan saran dari berbagai tokoh penelitian. Kemudian dilakukan dokumentasi dengan cara mengumpulkan data-data terkait tindakan pidana kejahatan Narkoba di Bukittinggi.

Teknik analisis data berpedoman kepada teknik analisis data yang dikemukan oleh Miles dan Hubermen yang terdiri dari reduksi data, penyajian data, dan pengambilan kesimpulan $^{11}$, keabsahan data penelitian diuji dengan triangulasi sumber, yaitu mengecek data atau informasi yang diperoleh melalui sumber yang berbeda seperti

\section{HASIL DAN PEMBAHASAN}

Lembaga Pemasyarakatan Kelas IIA Bukittinggi adalah "unit pelaksana teknis di bidang pemasyarakatan yang berada di bawah Kementrian Hukum dan Ham RI Cq

\footnotetext{
${ }^{10}$ Moleong. (2017), "Metodologi Penelitian Kualitatif”, Bandung: Remaja Rosdakarya.

11 Ghony dan Almanshur, (2016), "Metedologi Penelitian Kualitatif", Yogyakarta: ArRuzzmedia. https://doi.org/10.32696/jp2sh.v4i2.348
} 
e-ISSN : 2621-4105

Direktorat Jenderal Pemasyarakatan dan bertanggung jawab langsung kepada Kepala Kantor Wilayah Kementrian Hukum dan HAM Sumatera Barat”.

Lembaga Pemasyarkatan Kelas IIA Bukittinggi berada di wilayah Kecamatan IV Angkat Kabupaten Agam, tepatnya di Jl. Raya Bukittinggi - Payakumbuh Km.8 dari pusat kota Bukittinggi. Bangunan ini merupakan bangunan baru sebagai pengganti bangunan lama yang terletak di Jl. Perintis Kemerdekaan Bukittinggi yang dibangun oleh Pemerintah Hindia Belanda pada tahun 1858. Lembaga Pemasyarakatan Kelas IIA Bukittinggi yang terletak di Biaro sekarang di bangun pada tahun 1986 ditanah seluas $30.700 \mathrm{~m}^{2}$ dan difungsikan pada tanggal 18 November 1991 sampai sekarang.

Dalam Kamus Besar Bahasa Indonesia (KBBI), Narkoba adalah "akronium dari pada kata Narkotika, Psikotropika dan Obat berbahaya lainnya", Narkoba mempunyai banyak macam, bentuk, warna dan pengaruh tehadap tubuh dan fisik, Narkoba juga memiliki banyak persamaan, salah satunya adalah sifat ketegantungan di dalam zat Narkotika tersebut. Istilah Narkoba muncul pada tahun 1998 karena pada saat itu banyak terjadi penggunaan Zat termasuk Narkotika dan obat-obatan adiktif yang terlarang. Istilah ini digunakan untuk memudahkan orang berkomunikasi tanpa menyebutkan istilah yang tergolong panjang yaitu Narkotika, Psikotropika, dan Obat Berbahaya Lainnya.

Menurut alinea ke-2 Undang-undang No. 35 Tahun 2009 tentang Narkotika, Penyalahgunaan narkoba khususnya narkotika dan psikotropika adalah "bahaya laten yang setiap kali diberantas tak lantas habis tetapi akan tumbuh di tempat yang baru dengan modus yang berbeda". ${ }^{12}$ Zat ini dapat mengurangi sampai menghilangkan rasa nyeri dan dapat menimbulkan ketergantungan.

Pada dasarnya undang-undang narkotika menganut konsep strict liability mengandung unsur pertanggungjawaban mutlak. Artinya setiap orang yang memenuhi unsur-unsur pidana pada undang-undang narkotika dapat dipertanggungjawabkan secara mutlak. Sesuai tujuannya undang-undang narkotika sebagai yang tertuang dalam Pasal 4 UU Narkotika. Pasal tersebut bermakna bahwa keberadaan UU Narkotika dijadikan wadah utama untuk menyelamatkan Indonesia

12 Aang Munawar Juanda, "Pemberdayaan Penyuluh Agama Islam Dalam Upaya Penanggulangan Penyalahgunaan Narkotika Dan Psikotropika Di Kabupaten Sukabumi”, Jurnal Justicianelen 1 (1), 2021, hal 16-30. DOI: https://doi.org/10.35194/jj.v1i1.1112 
e-ISSN : 2621-4105

dari maraknya penyalahguna narkotika yakni dengan menjamin, dan mencegah penyebaran penyalahguna narkotika. ${ }^{13}$

Selain itu Mardani mengemukakan bahwa narkotika adalah "zat yang bisa menimbulkan pengaruh tertentu bagi mereka yang menggunakannya dengan memasukkannya kedalam tubuh. Pengaruh terhadap tubuh tesebut berupa pembiusan, hilangnya rasa sakit, rangsangan semangat dan halusinasi atau kahayalan-khayalan". Sifat tersebut diketahui dan ditemui dalam dunia medis yang betujuan untuk dimanfaatkan bagi penbobatan dan kepentingan manusia. Seperti di bidang pembedahan untuk menghilangkan rasa sakit. ${ }^{14}$

Psikotropika adalah Zat atau obat bukan narkotika, baik alamiah maupun sintetis, yang memiliki khasiat psikoaktif melalui pengaruh selektif pada susunan saraf yang menyebabkan perubahan khas pada aktifitas moral dan perilaku. ${ }^{15}$

Secara khusus diuraikan bahwa penyalahgunaan narkoba dalam dosis tinggi beresiko pada kerusakan pada susunan syaraf otak secara permanen. ${ }^{16}$ Lebih bahaya lagi jika pengunaan tidak disertai dengan resep dokter yang bisa berdampak pada kematian. Kerusakan pada syaraf otak yang disebabkan oleh penyalah gunaan obat karena zat aktif dan merusak susunan syaraf. ${ }^{17}$ Susunan syaraf merupakan bagian tubuh yang dipakai untuk berfikir, bereaksi dan mengatur gerak beberapa bagian tubuh lainya. Apalagi beberapa zat psikotropika dapat menimbulkan ketergantungan secara fisik dikenal dengan istilah adiksi dan ketergantungan psikis yang disebut habituasi. ${ }^{18}$

Narkoba menjadi suatu ancaman dan bahaya dalam masyarakat bila kurang waspada, dapat menjadi bencana yang bisa saja menimpa kita. Sebagai suatu pembanding, dapat kita rasakan betapa serius dan kompleksnya musibah bencana alam yang akhir-akhir ini terjadi di tanah air. Mengingatkan kepada kita tentang perlunya

${ }^{13}$ Deni Setya Bagus Yuherawan, Baiq Salimatul Rosdiana, “Ketidaktepatan Penjatuhan Pidana Penjara Terhadap Penyalahguna Narkotika”, Jurnal Ius Constituendum 5 (2), 2020 hal 177-195.

DOI : $\underline{10.26623 / \mathrm{jic} . \mathrm{v} 5 \mathrm{i} 2.2207}$

${ }^{14}$ Mardani, (2008). "Penyalahgunaan Narkoba Dalam Perspektif Hukum Islam Dan Hukum Pidana Nasional”. Jakarta: PT Raja Grafindo Persada.

${ }^{15}$ Fransisca Novita Eleonora, "Bahaya Penyalahgunaan Narkoba Serta Usaha Pencegahan Dan Penaggulanganya", Jurnal Ilmu Hukum 25 (1), 2011. DOI: http://dx.doi.org/10.26532/jh.v25i1.203

${ }^{16}$ Ma'sum. (2003), "Penanggulangan Bahaya Narkotika Dan Bahaya Ketergantungan Obat", Jakarta: CV Mas Agung.

${ }^{17}$ Sitanggang. (1999), "Pendidikan Pencegahan Penyalahgunaan Narkotika", Jarkata: Karya Utama.

${ }^{18}$ Waresniwiro. (1997), “Narkotika Bahaya”, Jakarta: Mitra Bintibmas. 
e-ISSN : 2621-4105

manajemen yang handal dalam menghadapi suatu bencana massal, tentu termasuk bencana bahaya akibat Narkoba.

Pemakaian Narkoba sangat mempengaruhi kerja otak yang berfungsi sebagai pusat kendali tubuh dan mempengaruhi seluruh fungsi tubuh. Karena bekerja pada otak, narkoba merubah suasana perasaan, cara berfikir, kesadaran dan perilaku pemakainya. Berdasarkan Itulah sebabnya Narkoba disebut zat psikoaktif. ${ }^{19}$

Ketergantungan terhadap seseorang yang memakai narkoba jika tidak timbul gejala putus zat jika pemakainnya dihentikan atau jumlahnya dikurangi, sehingga gejalanya bergantung pada jenis Narkoba yang digunakan. Gejala putus opioida (heroin) mirip orang sakit flu berat, yaitu hidung berair, keluar air mata, bulu badan berdiri, nyeri ot ot, mual, muntah, diare dan sulit tidur. ${ }^{20}$ Narkoba juga mengganggu fungsi organ-organ tubuh yang lain seperti jantung, paru, hati dan sistem produksi, sehingga dapat timbul berbagai penyakit.

Berdasarkan temuan penelitian dan analisis data penelitian, beberapa faktor yang ditemukan penyebab perempuan melakukan kejahatan narkotika adalah rendahnya pemahaman agama, faktor pendidikan, faktor lingkungan dan permasalahan dalam keluarga.

\section{Faktor Rendahnya Pemahaman Agama}

Agama merupakan sumber nilai bagi kehidupan. nilai-nilai yang terkandung dalam agama dipandang baik oleh orang yang yakin dan beriaman terhadap agama. konsekuensi keimanan melahirkan sikap tanduk dan patuh terhadap perintah dan larangan agama. sikap tunduk dan patuh merupakan konsekuensi kesadaran atas keyakinan bahwa setiap yang diperintahkan agama adalah kebaikan dan setiap yang dilarang agama adalah keburukan.

Namun, berbeda dengan manusia yang memiliki pemahaman yang rendah dan keyakinan yang rendah terhadap agama. Rendahnya pemahaman manusia terhadap agama menimbulkan sikap-sikap manusia yang cendrung melawan perintah dan larangan agama. salah satu yang terjadi adalah masih banyaknya manusia beragama yang terjebak dalam kejahatan narkoba. padahal agama sangat melarang perbuatan yang merugikan dan

${ }^{19}$ Rismanda Rismanda, "Faktor-Faktor Penyebab Tindak Pidana Penyalahgunaan Narkotika Di Kota Surakarta”. Jurnal Recidive 7 (1), 2014.

${ }^{20}$ Saanin Saanin, "Faktor Yang Berhubungan Dengan Penyalahgunaan Narkoba Di RSJ", Jurnal Kesehatan Masyarakat Andalas (JMKA). Vol 8 (2), 2014. 
e-ISSN : 2621-4105

merusak diri sendiri. Dari 370 narapida narkoba lembaga pemasyarakatan kelas II A Bukittinggi terdapat 352 orang beragama islam. Namun dalam wawancara dan pengamatan ditemukan bahwa mereka sangat jarang melakukan sholat, dzikir, dan mendengarkan ceramah-ceramah keagamaan.

2. Faktor Pendidikan

Faktor rendahnya pendidikan juga sangat mempengarui terjadinya tindakan kejahatan narkoba. melalui wawancara, pengamatan dan dokumentasi ditemukan bahwa narapida narkoba lembaga pemasyarakatan kelas II A bukittinggi memiliki pendidikan rendah. Rendahnya pendidikan narapida tersebut tidak terlepas dari rendahnya perekonomian sehingga mengharuskan untuk berkerja dan tidak bisa melanjutkan pendidikan. hal ini selanjutnya mendorong mereka untuk bekerja menjadi pengedar dan pemakai Narkoba. adapun data pendidikan narapida Narkoba lembaga pemasyarakatan kelas II A Bukittinggi dapat dilihat di tabel bawah ini:

Tabel 1

Tingkat Pendidikan Narapidana Narkotika di LP Kelas II A Bukittinggi

\begin{tabular}{|l|l|l|}
\hline No. & $\begin{array}{l}\text { Tingkat } \\
\text { Pendidikan }\end{array}$ & Jumlah \\
\hline 1. & SD & 90 \\
\hline 2. & SMP & 108 \\
\hline 3. & SMA & 166 \\
\hline 4. & D I/S1 & 6 \\
\hline Jumlah & $\mathbf{3 7 0}$ \\
\hline
\end{tabular}

Sumber: Data Lapas Kelas II A Bukittinggi, 2020

\section{Faktor Lingkungan}

Faktor lingkungan juga sangat berpengaruh terhadap terjadinya kejahatan narkoba. kebutuhan dalam pergaulan lingkungan dan lingkungan yang buruk menyebabkan mereka terjerumus pada narkoba. Menurut penjelasan dari kepolisian, tindak pidana penyalahgunaan narkoba yang diakibatkan oleh faktor lingkungan yaitu pelaku pada awalnya karena pengaruh teman-teman dilingkunganya. berawal dari kumpul-kumpul kemudian membeli narkoba untuk dipakai secara bersama-sama.

\section{Faktor keluarga}

Keluarga merupakan peletak dasar dari kepribadian seseorang. kelurga berfungsi sebagai pembentuk karakter dan sikap seorang anak karena keluarga merupakan 
e-ISSN : 2621-4105

lingkunagan pertama yang ditemui oleh seorang anak untuk tumbuh dan berkembang. Data yang ditemukan dalam tindakan pidana penyalahgunaan narkoba di Bukittinggi diakibatkan oleh hubungan yang tidak harmonis dalam keluarga. kurangya kasih sayang dari orang tua sangat memicu seorang anak terjerumus dalam mencari pelampiasan lain seperti narkoba. berdsarkan hasil wawancra dengan narapidana penyalahgunaan narkoba yang menjelaskan bahwa kurangya perhatian dari orang tua, orang tuanya sudah bercera sejak pelaku duduk dibangku sekolah dasar. pelaku tertekan karena tidak memiliki kelurga yang utuh sehingga menyebabkan pelaku prustasi dan stres. sehingga pelaku mulai mengenal narkoba untuk lari dari masalah yang dihadapinya.

\section{E. PENUTUP}

Berdasarkan hasil dan pembahasan di atas dapat disimpulkan bahwa faktor-faktor penyebab timbulnya kejahatan pidana narkoba adalah faktor rendahnya pemahaman agama, Rendahnya pemahaman manusia terhadap agama menimbulkan sikap-sikap manusia yang cendrung melawan perintah dan larangan agama. salah satu yang terjadi adalah masih banyaknya manusia beragama yang terjebak dalam kejahatan narkoba. Faktor rendahnya pendidikan, rendahnya pendidikan narapida tersebut tidak terlepas dari rendahnya perekonomian sehingga mengharuskan untuk berkerja dan tidak bisa melanjutkan pendidikan. hal ini selanjutnya mendorong mereka untuk bekerja menjadi pengedar dan pemakai Narkoba. Faktor lingkungan, Menurut penjelasan dari kepolisian, tindak pidana penyalahgunaan narkoba yang diakibatkan oleh faktor lingkungan yaitu pelaku pada awalnya karena pengaruh teman-teman dilingkunganya. berawal dari kumpul-kumpul kemudian membeli narkoba untuk dipakai secara bersama-sama. Faktor penyebab terakhir adalah faktor keluarga, baaimana keluarga merupakan peletak dasar dari kepribadian seseorang. Keluarga berfungsi sebagai pembentuk karakter dan sikap seorang anak karena keluarga merupakan lingkunagan pertama yang ditemui oleh seorang anak untuk tumbuh dan berkembang. 


\section{DAFTAR PUSTAKA}

\section{Buku}

Ghony dan Almanshur, (2016), “Metedologi Penelitian Kualitatif', Yogyakarta: ArRuzzmedia.

Mardani, (2008), "Penyalahgunaan Narkoba Dalam Perspektif Hukum Islam Dan Hukum Pidana Nasional”, Jakarta: PT Raja Grafindo Persada.

Ma’sum. (2003), "Penanggulangan Bahaya Narkotika Dan Bahaya Ketergantungan Obat", Jakarta: CV Mas Agung.

Moleong. (2017), "Metodologi Penelitian Kualitatif”, Bandung: Remaja Rosdakarya.

Sitanggang. (1999), "Pendidikan Pencegahan Penyalahgunaan Narkotika", Jarkata: Karya Utama.

Waresniwiro. (1997), “Narkotika Bahaya”, Jakarta: Mitra Bintibmas.

\section{Jurnal}

Aang Munawar Juanda, "Pemberdayaan Penyuluh Agama Islam Dalam Upaya Penanggulangan Penyalahgunaan Narkotika Dan Psikotropika Di Kabupaten Sukabumi”, Jurnal Justicianelen 1 (1), 2021.

DOI: https://doi.org/10.35194/ii.v1i1.1112

Bachri Bachri, "Meyakinkan Validitas Data Melalui Triangulasi Pada Penelitian Kualitatif', Jurnal Teknologi Pendidikan 10 (1), 2010.

Badan Narkotika Nasional, "Hasil Survei Penyalahgunaan Dan Peredaran Gelap Narkoba Pada Kelompok Pelajar Dan Mahasiswa Di 18 Provinsi Tahun 2016", Jurnal Data Puslitdatin BNN 10 (2), 2016.

Fransisca Novita Eleonora, "Bahaya Penyalah Gunaan Narkoba Serta Usaha Pencegahan Dan Penaggulanganya”, Jurnal Ilmu Hukum 25 (1), 2011.

DOI: http://dx.doi.org/10.26532/jh.v25i1.203

Deni Setya Bagus Yuherawan, Baiq Salimatul Rosdiana, "Ketidaktepatan Penjatuhan Pidana Penjara Terhadap Penyalahguna Narkotika”, Jurnal Ius Constituendum 5 (2), 2020. DOI : $\underline{10.26623 / \text { jic.v5i2.2207 }}$

Dian Arthauly Pangaribuan dkk, "Efektifitas Pemidanaan Terhadap Pelaku Tindak Pidana Narkotika: Studi Pengadilan Negeri Pasangkayu", Journal of Lex Generalis 1 (4), 2020. DOI: https://doi.org/10.52103/ilg.v1i4.181

Gunawan Gunawan, "Peran Masyarkat Dalam Pencegahan Dan Penanggulangan Terhadap Penyalahgunaan Dan Peredaran Gelap Narkotika", Jurnal Sociae Polites 15 (2), 2014.

Gomgom T.P. Siregar dkk,“Analisis Faktor-Faktor Penyebab Anak Melakukan Tindak Pidana Narkotika”. Jurnal Penelitian Pendidikan Sosial Humaniora 4 (2), 2019. https://doi.org/10.32696/ip2sh.v4i2.348

Hafrida Hafrida, "Kebijakan Hukum Pidana Terhadap Penggunaan Narkotika Sebagai Korban Bukan Pelaku Tindak Pidana: Studi Lapangan Daerah Jambi", Jurnal Padjajaran Jurnal Ilmu Hukum 3 (1).2016.

Iredo Fani Reza, "Peran Orang Tua Dalam Penanggulangan Penyalahgunaan Narkoba Pada Generasi Muda", Jurnal Psikologi Islami 2 (1), 2016. 
e-ISSN : 2621-4105

Maudy Pritha Amanda dkk, "Penyalahgunaan Narkoba Di Kalangan Remaja". Jurnal Penelitian dan PPM 4 (2), 2017. DOI: https://doi.org/10.24198/ippm.v4i2.14392

Novi Novitasari dkk, "Proses Penegakan Hukum Terhadap Tindak Pidana Penyalahgunaan Narkotika Yang Dilakukan Oleh Anak". Jurnal Pembangunan Hukum Indonesia 2 (1), 2021. DOI: https://doi.org/10.14710/iphi.v3i1.96-108

Rismanda Rismanda, "Faktor-Faktor Penyebab Tindak Pidana Penyalahgunaan Narkotika Di Kota Surakarta". Jurnal Recidive 7 (1), 2014.

Saanin Saanin, "Faktor Yang Berhubungan Dengan Penyalahgunaan Narkoba Di RSJ". Jurnal Kesehatan Masyarakat Andalas (2), 2014.

Tampubolon. "Peran Badan Narkotika Nasional (BNN) Dalam Penanggulangan Narkotika Di Kota Samarinda”, e-Jurnal Ilmu Pemerintah 3 (1), 2015 